MAŁGORZATA MĄCZKO ${ }^{1}$

\title{
NIE JESTEM JAK TY \\ MĘSKOŚĆ HEGEMONICZNA WE WSPÓŁCZESNYM POŁUDNIOWOAFRYKAŃSKIM KINIE QUEER
}

Słowa kluczowe: kino południowoafrykańskie, kino queer, RPA, męskość hegemoniczna

Kino od samego początku swojego istnienia bezustannie przyczynia się do rozpowszechniania i podtrzymywania konserwatywnych wzorców i stereotypów związanych z płcią. W ostatnich latach umożliwia ono jednak równoległy rozwój przeciwnej koncepcji, coraz częściej dopuszczając do głosu twórców, którzy w swoich dziełach ten porządek krytykują czy wręcz jawnie kontestują. W ich rękach film staje się narzędziem eksploracji mniejszościowych tożsamości oraz przestrzenią ich reprezentacji. Amerykańscy i europejscy twórcy, działający w ramach szeroko pojętego kina niezależnego, coraz chętniej sięgają po zmarginalizowane dotychczas narracje i zgłębiają problematykę związaną z życiem mniejszości seksualnych, etnicznych czy rasowych. Przyjmowana w tego typu produkcjach zachodnia perspektywa od lat dominuje w światowym kinie queer, lecz nie jest wcale jedyną opcją. Lokalne kinematografie krajów afrykańskich i azjatyckich również próbują opowiadać o doświadczeniach bohaterów nieheteronormatywnych, mierząc się przy tym nie tylko z niesprzyjającą sytuacją społeczną, lecz często również z niekorzystnymi realiami produkcyjno-dystrybucyjnymi. Różnorodne strategie twórcze pozwalają tamtejszym filmowcom na połączenie tematyki queer z lokalnymi kontekstami, czyniąc z ich dzieł obiekt fascynacji wśród zachodnich publiczności festiwalowych.

${ }^{1}$ Mgr; Uniwersytet Jagielloński; ORCID: 0000-0002-9226-8906; malgorzata.maczko@doctoral.uj.edu.pl. 
Jednym z państw, które w ostatnich latach mogły się poszczycić sukcesami na tym polu, jest Republika Południowej Afryki. W ciągu ostatniej dekady powstało tam kilka filmów, które zdobyły zarówno światowy rozgłos, jak i wywołały zażartą debatę publiczną w kraju. Trzy filmy z tego okresu - Piękno (Skoonheid, 2011, reż. O. Hermanus), Rana (Inxeba, 2017, reż. J. Trengove; $w$ artykule stosowany jest tytuł festiwalowy filmu, będący dosłownym tłumaczeniem tytułu oryginalnego; polski dystrybutor zmienił później jego brzmienie na Inxeba. Zakazana ścieżka) oraz Moffie (2019, reż. O. Hermanus) - zgłębiają odmienne doświadczenia życiowe nieheteroseksualnych południowoafrykańskich mężczyzn. Jednocześnie każde z tych dzieł stanowi komentarz do rozpowszechnionych w RPA wzorców męskości i obrazuje konsekwencje niedopasowania się jednostki do dominującego kulturowego modelu płci. Dzięki zastosowaniu teorii męskości hegemonicznej możliwe stanie się zarówno prześledzenie społecznych i historycznych uwarunkowań oraz źródeł postaw przyjmowanych przez poszczególnych bohaterów, jak i wskazanie punktów wspólnych ich życiowych doświadczeń, występujących mimo odmiennej przynależności rasowej i klasowej.

\section{UWARUNKOWANIA HISTORYCZNE I SPOŁECZNO-KULTUROWE}

Rozwój kinematografii południowoafrykańskiej był ściśle związany ze zmieniającymi się na przestrzeni lat układami władzy i relacjami społecznymi. Wielowiekowa historia europejskiego kolonializmu na tych terenach przyczyniła się do wytworzenia głębokich podziałów i długotrwałego wykluczenia niektórych grup z dostępu do władzy i samostanowienia, a w efekcie również do tworzenia własnych narracji, zarówno w obszarze życia społecznego, jak i sztuki. Także w kinie południowoafrykańskim swoje odzwierciedlenie przez długi czas znajdowały przede wszystkim idee zgodne ze światopoglądem klasy rządzącej, do której wstępu nie miały osoby odmiennej rasy czy orientacji seksualnej.

Trwająca od XVII wieku systemowa represja rdzennej ludności afrykańskiej nie ustała wraz z wycofaniem się sił imperium brytyjskiego. Także po uzyskaniu niepodległości nie dążono do zbudowania spójnej tożsamości narodowej, lecz usiłowano podtrzymać relacje władzy wprowadzone w epoce kolonialnej. Konsekwentnie wprowadzano również dodatkowe ograniczenia praw obywatelskich osób niebędących potomkami kolonizatorów. Polityka segregacji rasowej, czyli apartheid (dosł. bycie osobno), stała się 
oficjalną doktryną RPA w roku 1948, po dojściu do władzy Partii Narodowej, choć jak zauważa Krzysztof Maksymow, „wszystkie elementy supremacji białych i segregacji fizycznej"2 istniały już wcześniej. W życie wszedł wówczas jednak szereg nowych ustaw, które na niemal pół wieku ograniczyły prawa osób czarnoskórych i podzieliły społeczeństwo ze względu na kolor skóry. Demontaż tego systemu rozpoczął się dopiero u progu lat 90., pod naciskiem zachodnich mocarstw. W pierwszych demokratycznych wyborach na prezydenta wybrano represjonowanego w czasach poprzedniego ustroju prawnika, Nelsona Mandelę, który rozpoczął wieloletnią walkę z systemowym, instytucjonalnym rasizmem. Przeprowadzone w 2018 roku badania wskazują, że mimo tych wysiłków RPA pozostaje krajem głęboko podzielonym, a postawy przedstawicieli poszczególnych ras i grup społecznych zmieniają się niezwykle wolno3. Mandela od samego początku swojej prezydentury działał również na rzecz równouprawnienia i własną postawą starał się promować bardziej progresywne modele męskości. Jego następcy nie kontynuowali jednak tych dążeń, z czasem posuwając się do jawnego piętnowania projektu równościowego jako idei rzekomo antyafrykańskiej, sprzecznej z narodowym duchem i „równoznacznej z aspiracjami (białej) klasy średniej i szeroko zakrojonym brakiem (męskiego) postępu ekonomicznego 4 .

Dyskryminacja, jakiej doświadczała w XX wieku w RPA społeczność LGBTQ+, różniła się od szeroko zakrojonych represji, którym poddawano rdzennych i „kolorowych” mieszkańców tego kraju, lecz nie była wobec nich zjawiskiem całkowicie odrębnym. Era apartheidu była bowiem również okresem wprowadzania legislacji wymierzonej w osoby nieheteronormatywne. Transformacja ustrojowa przyniosła jednak diametralną poprawę ich sytuacji, a przyjęta w 1994 roku nowa, progresywna konstytucja zrównała prawa wszystkich obywateli, bez względu na rasę, tożsamość płciową czy orientację seksualną. Ponadto w 2006 roku RPA jako jeden z pierwszych krajów na świecie zalegalizowała związki jednopłciowe, choć,

${ }^{2}$ K. Maksymow, Przeobrażenia polityczne i społeczne w Południowej Afryce - od apartheidu do czasów współczesnych, „Forum Politologiczne” 2012, t. 13, s. 520.

${ }^{3}$ H. Hino, M. Leibbrandt, R. Machema i in., Identity, Inequality and Social Contestation in the Post-Apartheid South Africa, [w:] From Divided Pasts to Cohesive Futures. Reflections on Africa, eds. H. Hino, A. Langer, J. Lonsdale, F. Stewart, Cambridge 2019.

${ }^{4}$ R. Morrell, R. Jewkes, G. Lindegger, Hegemonic Masculinity/Masculinities in South Africa. Culture, Power, and Gender Politics, „Men and Masculinities” 2012, t. 15, nr 1, s. 18. 
jak zauważa Rivonia Pillay, „ochrona prawna wyprzedziła społeczną akceptację" ${ }^{5}$ i wciąż powszechne są postawy homofobiczne.

Opisany powyżej kontekst społeczny i polityczny pozwala zrozumieć, dlaczego w kinie południowoafrykańskim przez długi czas nie pojawiały się wątki homoseksualne, zwłaszcza w filmach, których akcja osadzona była w rdzennych społecznościach. Konserwatyzm światopoglądowy sprawia, że do dziś liczba filmów kontestujących patriarchalny, heteroseksualny porządek pozostaje mała. Zdaniem Martina Bothy początkowych przykładów pozytywnej reprezentacji mniejszości seksualnych dostarczyły dwa filmy: The Man Who Drove With Mandela (1998, reż. Greta Schiller) oraz Proteusz (Proteus, 2003, reż. Jack Lewis, John Greyson) 6 . Ukazują one odmienne oblicza południowoafrykańskiej społeczności LGBTQ+ oraz dokumentują jej obecność w RPA w różnych momentach historycznych, a także otwierają pole dla nowszych, bardziej progresywnych produkcji, które w ostatnich latach powstają coraz częściej.

Nie należy się jednak łudzić, że problem nierównego dostępu do medium filmu został wyeliminowany. W jednym z wywiadów była dyrektorka południowoafrykańskiego festiwalu Encounters, Mandisa Zitha, zauważała, że „większość przemysłu filmowego stanowią biali mężczyźni, z niewielkim udziałem czarnych reżyserów oraz kobiet"7, a do branży filmowej nie trafia wystarczająca liczba młodych twórców z grup mniejszościowych.

Kino RPA stawiało pierwsze kroki jeszcze w czasach kolonialnych, a rozwijało się w czasach apartheidu. Przez większość jego istnienia film nie był medium dostępnym dla wszystkich, a przedstawiane na ekranie historie w przeważającej mierze musiały być spójne z linią ideologiczną partii rządzącej. Stosunkowo krótki czas, który upłynął od upadku dawnego ustroju, sprawia, że filmowe wypowiedzi i narracje mniejszościowe wciąż pozostają zaledwie niewielkim procentem krajowej produkcji filmowej. Tym cenniejszym przedmiotem analizy wydają się zatem dzieła, którym nie tylko udało

${ }^{5}$ R. Pillay, South Africa Still Hasn't Won LGBTQ+ Equality. Here Are 5 Reasons Why, „World Economic Forum" 30 XI 2018, https://www.weforum.org/agenda/2018/11/south-africa-road-to-lgbtq-equality/ (dostęp 29 X 2020).

${ }^{6}$ M. Botha, Homosexuality and South African Cinema, "Kinema. A Journal for Film and Audiovisual Media” 2003; M. Botha, The Representation of Gays and Lesbians in South African Cinema 1985-2013, „Kinema. A Journal for Film and Audiovisual Media” 2013.

${ }^{7}$ R. Engel, Gender and Race in the South African Film Industry. A Comparative Analysis of the Representation in South African Film Festival, "Communicatio" 2018, t. 44, nr 1, s. 24. 
się zdobyć uznanie krytyki, lecz również uchwycić społeczne zależności, wiernie oddać splot okoliczności kształtujących tożsamość dzisiejszych południowoafrykańskich mężczyzn, a także obnażyć wciąż aktualne problemy związane z patriarchalną, rasistowską i homofobiczną przeszłością Afryki Południowej.

\section{MĘSKOŚĆ HEGEMONICZNA}

Dominujące w RPA modele męskości, ukształtowane na przestrzeni ostatnich dekad, można skutecznie analizować z wykorzystaniem teorii męskości hegemonicznej (hegemonic masculinity). Południowoafrykańscy autorzy chętnie powołują się na nią w swoich tekstach, wciąż aktualizując ją o nowe i lokalne konteksty. Ogólne założenia dotyczące tej kategorii zostały przedstawione w połowie lat 80. w artykule Toward a New Sociology of Masculinity, który stanowił krytyczny przegląd ówczesnego stanu studiów nad męskościami oraz spostrzeżeń na temat ról płciowych. Jako odpowiedź na niedociągnięcia rozpowszechnianych wówczas teorii autorzy zaproponowali kategorię męskości hegemonicznej, którą traktują jako „konkretny typ męskości, wobec którego inne typy - między innymi młodzi, zniewieściali i homoseksualni mężczyźni - są podporządkowane" ${ }^{\prime \prime}$. Hegemoniczna męskość jest ustanawiana $w$ relacji do grup podległych, wpisując się w schemat działania władzy patriarchalnej. Proponowany model męskości jest niemal nieosiągalny dla przeciętnych mężczyzn, lecz przyczynia się do podtrzymania ich społecznej dominacji nad kobietami i wyłamującymi się $z$ tradycyjnych schematów ekspresji płciowej mężczyznami. W grę wchodzą również inne zależności, wynikające między innymi z podziałów rasowych i klasowych, które mają wpływ na naturę relacji między poszczególnymi jednostkami. W późniejszym tekście Connell rozwijała refleksję na temat wykorzystanego $w$ tej teorii pojęcia hegemonii, zaczerpniętego z pism Antonio Gramsciego, opisując ją jako „przewagę społeczną, osiąganą w grze sił społecznych, która wykracza poza walkę o brutalną władzę i obejmuje organizację życia prywatnego oraz procesów kulturowych"9. Do

\footnotetext{
${ }^{8}$ T. Carrigan, B. Connell, J. Lee, Toward a New Sociology of Masculinity, „Theory and Society" 1985, nr 14, s. 587.

${ }_{9}^{9}$ R.W. Connell, Gender and Power. Society, the Person and Sexual Politics, Cambridge 1987.
} 
wytwarzania tego typu społecznej przewagi przyczyniają się między innymi religia, media, a także szeroko pojęte uwarunkowania polityczne i ekonomiczne. Jest to jeden z powodów, dla których kategoria hegemonicznej męskości jest wyjątkowo przydatna w analizie filmów - kino jest częścią systemu budującego dominację grup uprzywilejowanych.

Robert Morrell w 1998 roku podjął próbę przeniesienia koncepcji hegemonicznej męskości na grunt południowoafrykański. Podobnie jak Connell, dostrzega on współistnienie różnorodnych męskości, funkcjonujących

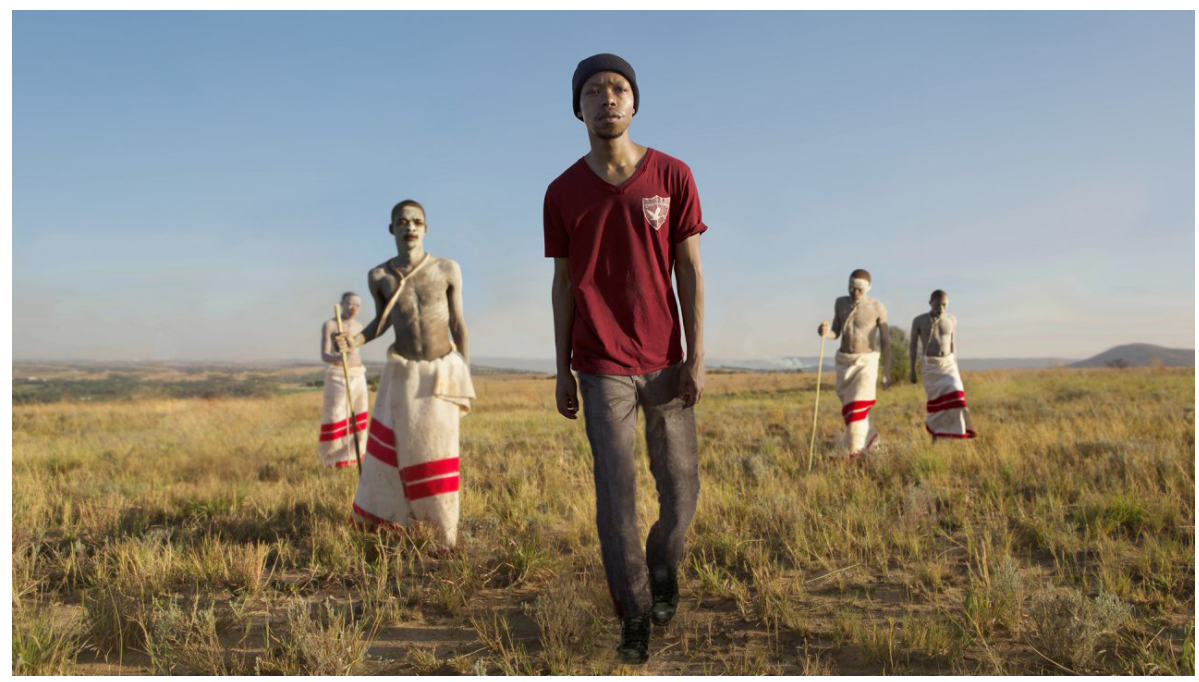

Rana (Inxeba. Zakazana ścieżka), 2017, reż. John Trengove, Francja-Holandia-Niemcy-RPA, dystr. Tongariro Releasing

w ramach jednego społeczeństwa. Jego zdaniem do koegzystencji wielu modeli męskości w RPA doszło w wyniku konkretnego splotu okoliczności historyczno-społecznych. Paradoksalnie, to segregacja rasowa przyczyniła się do zachowania rdzennych wzorców męskości, którym udało się przetrwać dzięki utrzymaniu ciągłości struktur plemiennych. Zepchnięte na margines lokalne społeczności podtrzymywały wielowiekowe tradycje, także te związane z hierarchią płciową. Choć możliwość ekspresji własnej tożsamości była ograniczona, a niektóre praktyki uległy zniekształceniu, to fundamenty życia społecznego rdzennych mieszkańców tego regionu zostały utrzymane. 
Morrell proponuje wyszczególnienie trzech typów męskości, które współistniały w strukturach społecznych RPA i wszystkie funkcjonowały jako męskości hegemoniczne. Pierwszy rodzaj to biała męskość, zakorzeniona w historii kolonialnej dominacji, która „przyczyniła się do zjednoczenia białych mężczyzn, zapewniła wzorce kulturowe i patriarchalny porządek, w którym władza jest nierównomiernie rozłożona pomiędzy mężczyzn i kobiety"10. Dwa pozostałe typy, nazywane przez Morrella męskością „afrykańską" oraz „czarną”, dotyczą mężczyzn z rdzennych społeczności Afryki Południowej, przy czym pierwsza z nich związana jest z tożsamością wiejską i lokalną, a druga konstruowana jest w kontekście miejskim, choć bez całkowitego zerwania z lokalnością.

Mogły zaistnieć sytuacje, w których wskazane modele męskości współdziałały ze sobą, by skuteczniej kontrolować podporządkowane wobec nich wszystkich grupy - czarne kobiety oraz czarnych nieheteroseksualnych mężczyzn. Jednak w zależności od kontekstu społecznego każdy typ uzurpował sobie prawo do bycia męskością hegemoniczną. Na poziomie lokalnym to afrykańska, a później również czarna męskość była dominującym wzorcem, określającym się w relacji do kobiet i młodszych mężczyzn z rdzennych, „prekolonialnych” społeczności ${ }^{11}$. Natomiast biała męskość była w XX wieku w RPA przepustką do władzy, sprawowanej nad niebiałymi obywatelami i obywatelkami. Rację miała więc Belinda Bozzoli, gdy zauważała, że w Afryce Południowej mamy do czynienia z „patchworkiem patriarchatów", w którym na przegranej pozycji zawsze znajdują się kobiety ${ }^{12}$.

$\mathrm{Na}$ okoliczności wytwarzania hegemonicznych wzorców męskości zwraca uwagę również Peter J. Kareithi. Wyszczególnia on kilka zjawisk, wskazywanych wcześniej także przez Connell, które organizują lokalne i globalne wyobrażenia na temat tego, jak powinien wyglądać i zachowywać się „prawdziwy” mężczyzna. Za ważny czynnik Kareithi uznaje kino hollywoodzkie, które od lat promuje brutalnych, hipermęskich bohaterów kina akcji; lokalne odpowiedniki tego typu postaci można odnaleźć również w innych kinematografiach, „od indyjskiego Bollywoodu po nigeryjski

${ }^{10}$ R. Morrell, Of Boys and Men. Masculinity and Gender in Southern African Studies, „Journal of Southern African Studies” 1998, nr 24, s. 619.

${ }^{11}$ Ibidem, s. 620.

12 B. Bozzoli, Marxism, Feminism and South African Studies, „Journal of Southern African Studies" 1983, t. 9, nr 2, s. 149. 
Nollywood"13. W przestrzeni kultury masowej istotną rolę odgrywają również teledyski, gry komputerowe oraz reklamy. Ponadto symbolika męskości jest mocno związana ze światem sportu oraz militariów, w których dominują kult tężyzny fizycznej i przyzwolenie na akty agresji. W kontekście południowoafrykańskim do tej listy można dopisać jeszcze świat polityki, który w kwestii promowanych wzorców męskości na przestrzeni ostatnich trzech dekad przeszedł od progresywnych idei Mandeli do „męskości heteroseksistowskej, patriarchalnej, domyślnie przemocowej i gloryfikującej męskie uprzywilejowanie seksualne"14, popieranej przez jednego z kolejnych prezydentów, Jacoba Zumę.

Rozważania na temat dominujących kulturowych modeli męskości warto zakończyć przytoczeniem kilku uwag bell hooks zawartych w Black Looks. Race and Representation. Choć autorka skupia się przede wszystkim na realiach amerykańskich, to jej uwagi na temat systemów patriarchalnych wydają się trafne również w kontekście południowoafrykańskim. Zauważa ona, że w bardziej tradycyjnych czarnych społecznościach bycie mężczyzną bywa często równoważne $z$ „dążeniem do męskiej tożsamości zakorzenionej w patriarchalnych ideałach"15. Skutkiem takiego myślenia jest wypieranie alternatywnych form męskości przez lokalne społeczności oraz silna internalizacja wzorców patriarchalnych. Mimo zauważalnej niechęci do inności czarna męskość nie jest jednak bytem monolitycznym, a skłonność do generalizacji jedynie utrudnia odkrycie jej prawdziwej, zróżnicowanej natury. Dla hooks kluczowy wydaje się postulat podważania uproszczonych patriarchalnych wzorców postępowania i poświęcenia większej uwagi kontestującym ten porządek formom męskości. Dotyczy to również będącej częścią dotychczasowego układu sił tzw. obowiązkowej heteroseksualności (compulsory heterosexuality), która prowadziła do homofobii, burząc jednocześnie poczucie wspólnoty i solidarności wśród czarnych mężczyzn ${ }^{16}$.

${ }^{13}$ P.J. Kareithi, Hegemonic Masculinity in Media Contents, [w:] Media and Gender. A Scholarly Agenda for the Global Alliance on Media and Gender, red. A.V. Montiel, Paris 2014, s. 27.

${ }^{14}$ R. Morrell, R. Jewkes, G. Lindegger, Hegemonic Masculinity/Masculinities in South Africa..., op. cit., s. 17.

${ }^{15}$ b. hooks, Black Looks. Race and Representation, New York, NY 1992, s. 87-88.

${ }^{16}$ Ibidem, s. 112. 


\section{MOFFIE: PRZYSPIESZONY KURS AFRYKANERSKIEJ MĘSKOŚCI}

Przykład trzech niedawnych południowoafrykańskich filmów opowiadających o doświadczeniach nieheteroseksualnych mężczyzn pozwala zilustrować, w jaki sposób w tamtejszych narracjach przejawia się wciąż oddziaływanie opisanego powyżej układu sił. Choć czas akcji, a także przynależność klasowa i rasowa bohaterów różnią się od siebie, to każde z omawianych dzieł pomoże wyjaśnić, na jakich poziomach jest konstruowana południowoafrykańska męskość hegemoniczna oraz w jaki sposób bywa ona kontestowana. Dwa filmy Olivera Hermanusa - Piękno oraz Moffie - opowiadają o białych bohaterach, których orientacja seksualna sprawia, że nie pasują do wyznawanego przez ich najbliższe otoczenie ideologicznego porządku. W obu dziełach poruszony zostaje problem toksycznej męskości, ufundowanej na rasizmie, mizoginii i homofobii. Alternatywną, lokalną wersję hegemonicznej męskości przedstawia natomiast Rana Johna Trengove'a, której akcja toczy się w czasie rytuału przejścia grupy etnicznej Xhosa.

Wspólne omówienie tych dzieł warto rozpocząć od kilku uwag na temat najnowszego filmu Hermanusa. Osadzony w latach 80. Moffie opowiada o doświadczeniach nastoletniego Nicholasa (Kai Luke Brummer), odbywającego obowiązkową służbę wojskową w czasach południowoafrykańskiej wojny granicznej z Angolą. Bohater staje się tam niemym świadkiem wojskowej indoktrynacji i jej wpływu na psychikę innych młodych rekrutów. Już pierwszego dnia słyszą oni od dowódcy, że „komunizm, lenistwo, pedalstwo i sympatia do czarnuchów nie będą tolerowane", a każdy kolejny dzień ma przypominać im o tej regule. Zgodnie z linią ideologiczną Partii Narodowej chłopcom wpaja się przekonania rasistowskie i homofobiczne, jednocześnie dając przyzwolenie na przemoc wobec grup mniejszościowych. Normalizacja takich zachowań jest jedną z pozostałości dawnego systemu, a zrozumienie jej źródeł jest istotne również w kontekście pozostałych omawianych filmów.

Na wyjaśnienie zasługuje już sam tytuł filmu. Słowo moffie jest homofobiczną obelgą, stosowaną zwykle pod adresem młodych, zniewieściałych mężczyzn. Shaun de Waal zaznacza, że w ostatnich latach określenie to jest stopniowo odzyskiwane przez lokalną społeczność LGBTQ+ na własny użytek, analogicznie do słowa queer $w$ krajach anglosaskich ${ }^{17}$. W filmie Herma-

${ }^{17}$ S. de Waal, Etymological Note: on "Moffie”, [w:] Defiant Desire. Gay and Lesbian Lives in South Africa, eds. M. Gevisser, E. Cameron, New York, NY 1995, s. xiii. 
nusa jest ono jednak używane w oryginalnym kontekście, mającym napiętnować niektórych rekrutów jako zbyt słabych i delikatnych, by odnaleźli się w wojskowym rygorze.

Homofobia zobrazowana zostaje jako zjawisko powszechne w strukturach armii, zarówno wśród nastoletnich żołnierzy, jak i wśród ich dowódców. Rzucenie na kogoś podejrzenia o bycie homoseksualistą jest jednym z najpoważniejszych oskarżeń, które dla podejrzanego może się skończyć poważnymi konsekwencjami - ciężkim pobiciem, zesłaniem do owianego złą sławą szpitalnego Oddziału 22, a w skrajnych przypadkach doprowadzeniem do samobójstwa. Główny bohater filmu Hermanusa przygląda się losowi kolegów z dystansu, w milczeniu ważąc własne losy. Z innym młodym żołnierzem, Dylanem Stassenem, łączy go bliska relacja i przelotny, potajemny pocałunek. Początkowo są one dla Nicholasa źródłem radości, prowadzą nawet do młodzieńczego zakochania, lecz z czasem nabierają obciążającego charakteru. Rozmawiając z rekrutem zmaltretowanym po oskarżeniach o homoseksualizm, Nicholas przyjmuje postawę defensywną i zaprzecza własnej naturze, mówiąc w złości: „Nie jestem jak ty”. Kiedy Stassen trafia do wojskowego szpitala na Oddział 22, chłopak próbuje nawiązać z nim kontakt, co udaje się dopiero po zakończeniu służby. Wtedy nie spotyka już jednak zadziornego nastolatka, lecz złamanego młodego mężczyznę po przejściach, który boi się nawet najmniejszego intymnego kontaktu z osobą tej samej płci.

Konkluzja, do której dochodzi w swoim filmie Hermanus, jest niezwykle gorzka. Rodziny witają powracających synów jako pełnoprawnych mężczyzn, ignorując nieodwracalne zmiany psychiczne, jakie zaszły w nich podczas pobytu w wojsku. Niektórzy byli w stanie przystosować się do rygorystycznych reguł lepiej niż inni, lecz wszyscy zostali nakarmieni patriarchalną, rasistowską propagandą, która każe białym mężczyznom wierzyć we własną dominację i prawo posiadania. Dotyczy ono nie tylko zajmowanych terenów, ale również ich mieszkańców - jeden z dowódców więzi grupę czarnych kobiet i dzieci, które mają jego żołnierzom dostarczać „,rozrywki". Ponadto jednym z wymogów stawianych rekrutom przez armię jest wyzbycie się ludzkich odruchów i wrażliwości na cudze cierpienie. W osiągnięciu pełnej obojętności niektórzy żołnierze pomagają sobie morfiną, inni wyraźnie stale balansują na skraju wytrzymałości psychicznej. Także Nicholas, który przez większość czasu obserwuje cierpienie innych młodych mężczyzn, odsuwając od siebie własne wątpliwości, przechodzi znaczącą przemianę z nieśmiałego chłopca w żołnierza mającego krew na rękach. 
Raz przyjęta ideologia zbudowana na rasizmie, mizoginii i homofobii zostaje z młodymi mężczyznami na lata i ma realny wpływ na kształtowanie ich tożsamości. Wojsko jest jedną z przestrzeni, w których propagowany jest konkretny model białej, heteroseksualnej męskości, określany w opozycji do tożsamości mniejszościowych. Jedyna w filmie retrospekcja przypomina jednak, że także w życiu codziennym przejawy zainteresowania osobami tej samej płci były piętnowane, a podejrzewani o homoseksualizm chłopcy poddawani ostracyzmowi. Proponowana $w$ dobie apartheidu wizja niekończącej się supremacji jednej grupy społecznej sprawiła, że zjednoczenie narodu po upadku dawnego ustroju okazało się zadaniem niezwykle trudnym.

\section{PIĘKNO: MĘSKOŚĆ PO TRANSFORMACJI}

W wyniku przemian systemowych wielu białych obywateli RPA z dnia na dzień znalazło się w zupełnie nowej rzeczywistości społeczno-politycznej, w której musieli redefiniować relacje łączące ich z rodakami odmiennej rasy. Efektem gwałtownych przemian było zagubienie, mogące rodzić przemoc i niechęć. Choć wiele wysiłku włożono w projekt integracji społecznej, to wciąż istnieją środowiska, które chciałyby wrócić do dawnego porządku, segregacji rasowej i politycznej dominacji rasy białej. Osoby wywodzące się z takiego otoczenia reagują negatywnie na wszelkie przejawy odmienności, nawet jeśli same nie są w stanie w pełni realizować norm narzucanych innym.

Podobną filozofię życiową wyznaje François van Heerden (Deon Lotz), bohater wcześniejszego filmu Hermanusa. W Pięknie reżyser skupia się na losach mężczyzny w średnim wieku, który na co dzień wiedzie z żoną spokojne życie na przedmieściach Bloemfontein, gdzie cieszy się powszechną sympatią i szacunkiem. Rysą na starannie konstruowanym wizerunku surowego patriarchy są utrzymywane $w$ tajemnicy przed bliskimi wypady za miasto na homoseksualne orgie. Żaden z ich uczestników nie identyfikuje się jednak jako gej - wręcz przeciwnie, na spotkaniach obowiązuje wiernie przestrzegana zasada „żadnych ciot, żadnych kolorowych" (afr. geen moffies, geen kleurlinge). Przypadkowe spotkanie François z synem znajomych, Christianem (Charlie Keegan), staje się początkiem nieodwzajemnionego, obsesyjnego uczucia. W finale filmu, po dokonaniu brutalnego gwałtu na młodym chłopaku, bohater wraca do dawnego życia u boku żony. 
François stara się realizować ten sam przebrzmiały model hegemonicznej afrykanerskiej męskości, który wpajano bohaterom osadzonego w latach 80. filmu Hermanusa. Theo Sonnekus opisuje ten typ męskości jako „tożsamość ukształtowaną przez wpojone uprzedzenia, opierające się na połączeniu białości, rasizmu i homofobii"18. Tożsamość François jest nie tylko sumą jego uprzedzeń, ale również świadomie budowaną fasadą. Bohater podejmuje szereg działań, które w jego mniemaniu dystansują go od grup mniejszościowych, znajdujących się w hierarchii społecznej niżej niż heteroseksualni, biali mężczyźni.

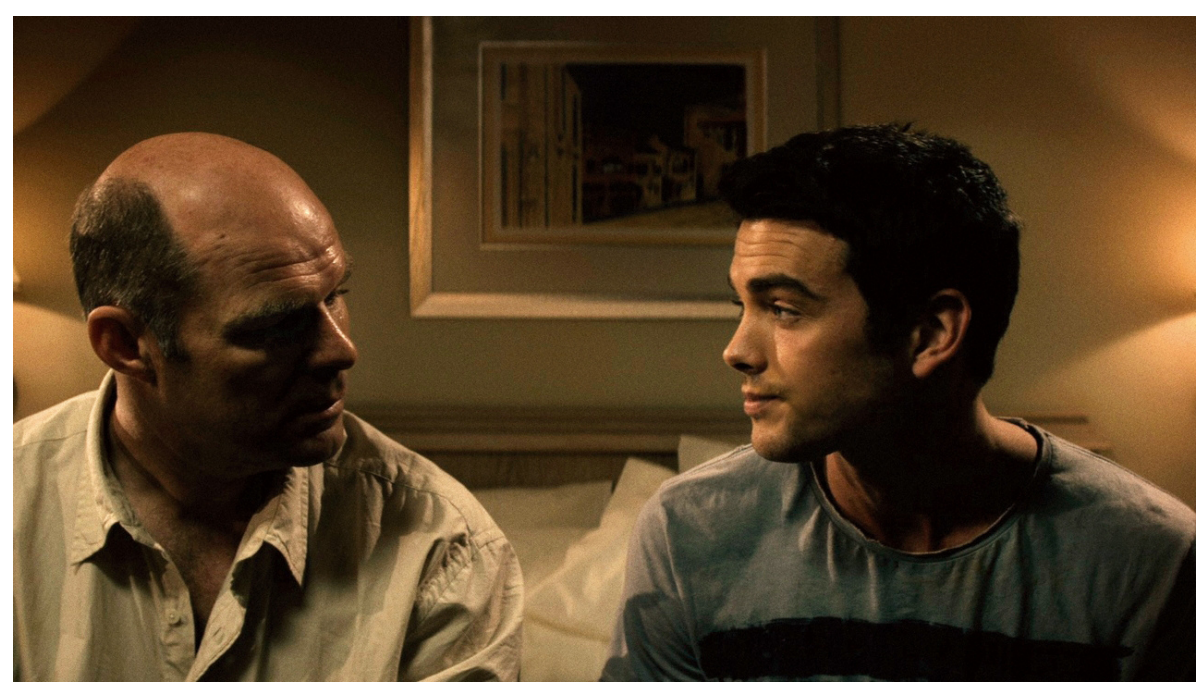

Piękno, 2011, reż. Oliver Hermanus, Niemcy-Francja-RPA, dystr. Tongariro Releasing

Chęć oddzielenia się od wyobrażonych Innych jest zauważalna między innymi na poziomie konstrukcji przestrzeni w filmie. Już sam wybór miejsca akcji jest nieprzypadkowy - reżyser w wywiadach nazywał Bloemfontein:

${ }^{18}$ T. Sonnekus, "We're not Faggots!". Masculinity, Homosexuality and the Representation of Afrikaner Men Who Have Sex with Men in the Film Skoonheid and Online, "South African Review of Sociology" 2013, t. 44, nr 1, s. 23. 
„bastionem afrykaneryzmu (Afrikaanerdom)”19, zwracając jednocześnie uwagę na wyjątkowo wysoki odsetek homoseksualizmu w tym mieście ${ }^{20}$. Napięcie między tymi dwoma czynnikami - silnym przywiązaniem do konserwatywnych wartości i ukrywanym nieheteroseksualnym pożądaniem jest kluczem do zrozumienia tożsamości François.

Bohater stara się fizycznie rozdzielić dwie sfery swojego życia, a droga, którą pokonuje, by dotrzeć na spotkanie z innymi mężczyznami, działa niczym bufor między sprzecznymi elementami jego tożsamości. Również sam domek za miastem, w którym odbywają się męskie orgie, jest wyraźnie podzielony: w pierwszym pomieszczeniu bywalcy tych spotkań rozmawiają na bezpieczne tematy, a dopiero $\mathrm{w}$ drugim, zaciemnionym pokoju dochodzi do erotycznych zbliżeń. Grant Andrews słusznie zauważa, że taka kompozycja „demonstruje represję męsko-męskiego pożądania, z którą mierzą się ci mężczyźni; jedyna przestrzeń, w której mogą okazywać pociąg do osób tej samej płci, wiąże się z ukrywaniem się w ciemności i z zamknięciem w małym pokoju"21. Także gwałt na Christianie ma miejsce w klaustrofobicznej przestrzeni słabo oświetlonego pokoju hotelowego.

Język, którego używają biali bohaterowie, również piętnuje wszelkie przejawy inności i stawia wyraźną granicę między "nami” a „nimi”. Winą za swoje uprzedzenia bohaterowie obarczają osoby, które są obiektem ich nienawiści i jako Inni zaburzają funkcjonowanie wspólnoty. Sam François w jednej ze scen wyznaje: „Nie było łatwo, ale kiedyś czuliśmy się bezpieczni. Teraz zmuszają nas, żebyśmy stawali się rasistami". Bohater postrzega swój rasizm jako postawę obronną, przyjętą w sytuacji zagrożenia statusu społecznego. Odpowiedzią na niepewność, związaną z gwałtowną transformacją ustrojową i utratą przywilejów, jest okopanie się na konserwatywnych pozycjach, które pomagają podtrzymać iluzję nieprzerwanej dominacji. Warto zauważyć, że u François poczucie utraty kontroli wzmaga przejawy agresji, zarówno psychicznej (wobec żony i córki), jak i fizycznej (gwałt), mającej dać bohaterowi na powrót namiastkę władzy

${ }^{19}$ R. Phillips, Filmmaker Oliver Hermanus Discusses Beauty, "World Socialist Web Site" 4 VIII 2012, https://www.wsws.org/en/articles/2012/08/sfoh-a04.html (dostęp 29 X 2020).

${ }^{20}$ L. Sampson, Cries and Whispers, "Sunday Times” 14 VIII 2011, https://www.timeslive.co.za/sunday-times/lifestyle/2011-08-14-cries-and-whispers/ (dostęp 29 X 2020).

${ }^{21} \mathrm{G}$. Andrews, The Boundaries of Desire and Intimacy in Post-apartheid South African Queer Film. Oliver Hermanus's Skoonheid, „Image and Text” 2018, nr 31, s. 35, http:// www.scielo.org.za/pdf/it/n31/02.pdf (dostęp 29 X 2020). 
i sprawczości. Dokonując napaści na Christiana, François wpisuje się w wyobrażenie o „białym mężczyźnie, którego wściekłość z powodu utraty władzy prowadzi do brutalnej konfrontacji i który wierzy, że ma fundamentalne prawo do sprawowania kontroli nad tymi, którzy są jeszcze słabsi niż on sam"22.

François buduje swoją tożsamość poprzez wytyczanie granic między sobą a osobami z grup społecznych, które uważa za podporządkowane. Powszednia homofobia i rasizm są pozostałościami po opresyjnym syste-

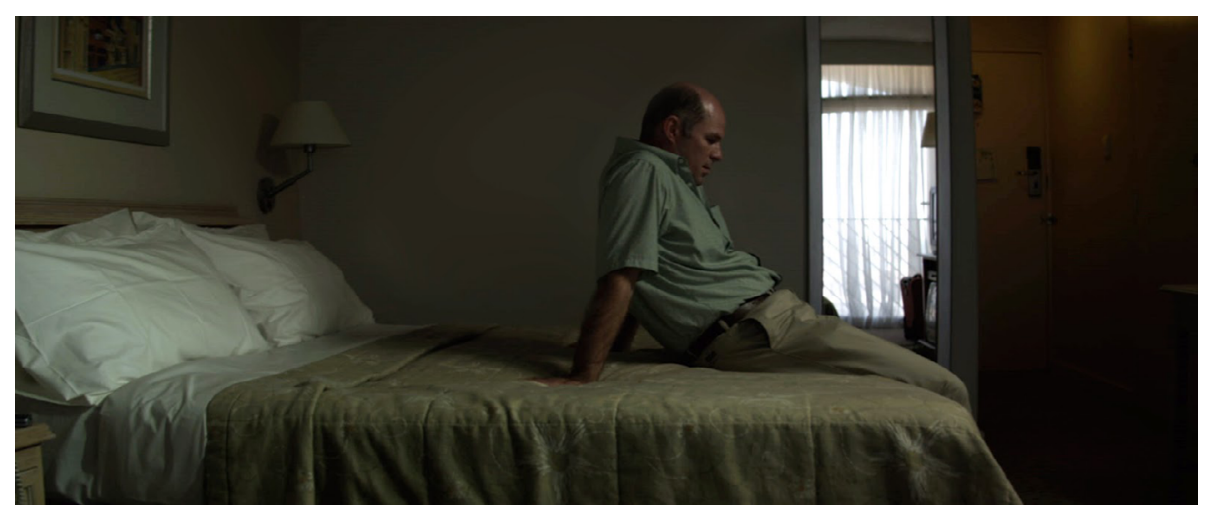

Piękno, 2011, reż. Oliver Hermanus, Niemcy-Francja-RPA, dystr. Tongariro Releasing

mie politycznym, lecz wciąż stanowią fundament afrykanerskiej męskości hegemonicznej. Jest ona jednak modelem przebrzmiałym, od lat znajdującym się w kryzysie, którego poplecznicy tej postawy zdają się nie zauważać. W swoich filmach Hermanus przedstawia męskość hegemoniczną jako pewien proces, którego źródła i sposoby oddziaływania obrazuje w Moffie. W Pięknie reżyser skupia się już na konsekwencjach zinternalizowania tego modelu oraz zwiastuje jego zmierzch.

${ }^{22}$ N. Falkof, ENG/AFR. White Masculinity in Two Contemporary South African Films, „Critical Arts" 2016, t. 30, nr 1, s. 25-26. 


\section{RANA: RYTUALNE WKRACZANIE W MĘSKOŚĆ}

Wśród rdzennych ludów południowoafrykańskich nauce męskości często towarzyszy tradycyjny obrzęd wkraczania w dorosłość, pomagający zachować ciągłość lokalnych modeli hegemonicznej męskości. Jednym z wciąż praktykowanych na terenie RPA rytuałów męskiej inicjacji jest ulwaluko, czyli ceremonia obrzezania nastoletnich chłopców z grupy etnicznej Xhosa. Szczegóły jej przebiegu są objęte tabu, rzadko więc bywają one obrazowane w mediach. John Trengove złamał nakaz milczenia, narażając się na negatywną reakcję lokalnej publiczności, i podjął w Ranie temat przekazywania rdzennych wzorców męskości, analizując również sposób, w jaki rytuał kształtuje tożsamość młodych mężczyzn Xhosa. W filmie istotne jest również zderzenie nowoczesności z lokalną tradycją. Opowiada on o nastoletnim Kwandzie (Niza Jay Ncoyini), wychowanym w Johannesburgu i zmuszonym do udziału w ceremonii przez ojca, który bezustannie kwestionuje zasady rytuału i lokalną hierarchię społeczną. Wprowadzający go w tajniki ulwaluko opiekun, Xolani (Nakhane), sam nie wpisuje się w model męskości Xhosa. Od lat łączy go potajemny romans z mentorem innej grupy nowicjuszy, Viją (Bongile Mantsai). Do konfrontacji między trzema bohaterami dochodzi po tym, jak Kwanda przyłapuje parę kochanków w intymnym uścisku. W tragicznym finale filmu Xolani zabija nastolatka, by ten nie wyjawił nikomu ich tajemnicy.

W dostępnych materiałach na temat ulwaluko na pierwszy plan wysuwają się dwie kwestie: odrzucenie nowoczesnych procedur medycznych jako niemęskich oraz zachowanie obojętności w obliczu bólu jako dowód siły. Ryzyko związane z przeprowadzeniem zabiegu obrzezania w niesterylnych warunkach jest wysokie, lecz poddanie się temu procesowi w szpitalu jest postrzegane przez tradycjonalistów Xhosa jako oznaka słabości i „skażenie czymś kompletnie obcym”23. Richard Bullock przytacza w swoim reportażu wypowiedź jednego z uczestników rytuału, który stwierdza wręcz, że „woli umrzeć, niż pójść do szpitala” ${ }^{24}$. Podobny system wartości

${ }^{23}$ L. Manona, A. Hurst, "What Is It to Be a Man?". Rites, Hashtags, Outrage, "Image and Text" 2018, nr 32, s. 5.

${ }^{24}$ R. Bullock, It's Hard to Be a Man, „Africa Geographic” 29 V 2015, https://africageographic.com/stories/xhosa-circumcision-ritual-south-africa-its-hard-to-be-a-man/ (dostęp 29 X 2020). 
młodemu bohaterowi Rany narzuca ojciec, który ma uznać Kwandę za pełnoprawnego mężczyznę dopiero po dopełnieniu rytuału.

Warto odnotować, że doświadczenie bólu jest elementem rytuałów przejścia w różnych kulturach. Mircea Eliade pisze o "mękach inicjacyjnych", które prowadzą do rytualnej śmierci ${ }^{25}$. Pozwalają one inicjowanym odrodzić się na nowo oraz połączyć się z kręgiem przodków. Również Robert Bly w Żelaznym Janie dostrzega, że różnego rodzaju zranienia są integralną częścią procesu wtajemniczenia. Zwraca on jednak uwagę, że zadana ciału rana często ma przypominać o doświadczonym uprzednio cierpieniu emocjonalnym, o "ranach duszy”. Ich przyczyny mogą być różne, od odrzucenia przez ojca po funkcjonowanie poza męską wspólnotą ${ }^{26}$.

Powyższe spostrzeżenia pozwalają zrozumieć, dlaczego udział w ulwaluko jest ważny dla mężczyzn nieheteroseksualnych. Uczestnictwo w rytuale pozwala im między innymi na uzyskanie większej władzy i przywilejów oraz podnosi ich status społeczny ${ }^{27}$. Zdaniem autorów artykułu The Role of Xhosa Traditional Circumcision in Constructing Masculinity ulwaluko odgrywa dominującą rolę w kulturze Xhosa i przyczynia się do podtrzymania ciągłości rdzennego modelu męskości hegemonicznej. Uczestnikom ulwaluko na długo przed faktycznym przystąpieniem do procesu inicjacji przedstawia się go jako oczywistą, naturalną kolej rzeczy. Za niedostosowanie się do wymogów stawianych przez lokalną społeczność mężczyzn może spotkać kara fizyczna lub słowne upomnienie. W ten sposób „ulwaluko zapewnia dominację, podtrzymuje zgodność i podporządkowuje sobie alternatywne męskości"28, od najmłodszych lat wpajając chłopcom z tej społeczności, że istnieje tylko jeden właściwy wzorzec postępowania. Później, już podczas rytuału, młodzi mężczyźni mają przyswoić sobie cechy idealnego mężczyzny Xhosa, takie jak: „poczucie tożsamości i przynależności, decyzyjność, zdolność rozwiązywania problemów, samokontrola, zdolności przywódcze, znajomość tradycyjnych rytuałów i przebiegu ceremonii, ciężka praca, samowystarczalność i wytrzymałość" ${ }^{\prime 29}$. Tak obszerna lista wymagań

${ }^{25}$ M. Eliade, Inicjacja, obrzędy, stowarzyszenia tajemne. Narodziny mistyczne, przeł. K. Kocjan, Kraków 1997, s. 56.

${ }^{26}$ R. Bly, Żelazny Jan, przeł. J. Tittenbrun, Poznań 2017.

${ }^{27}$ T. Magodyo, M. Andipatin, K. Jackson, The Role of Xhosa Traditional Circumcision in Constructing Masculinity, "South African Journal of Psychology” 2017, t. 43, nr 3, s. 345.

28 Ibidem, s. 349.

${ }^{29}$ Ibidem, s. 350. 
stawianych mężczyznom u progu dorosłości sprawia, że wielu z nich obawia się, iż im nie sprosta; dochodzi więc do negocjowania tego ideału i prób wytworzenia własnej wersji męskości.

Model męskości, który próbuje się zaszczepić uczestnikom obrzędu ulwaluko, wręcz wzorcowo spełnia więc założenia męskości hegemonicznej, wykluczającej alternatywne postawy. W Ranie większość chłopców nie próbuje kwestionować zasad rytuału i tylko Kwanda postrzega męskość Xhosa jako koncepcję opresyjną. Bohater podważa autorytet lokalnej

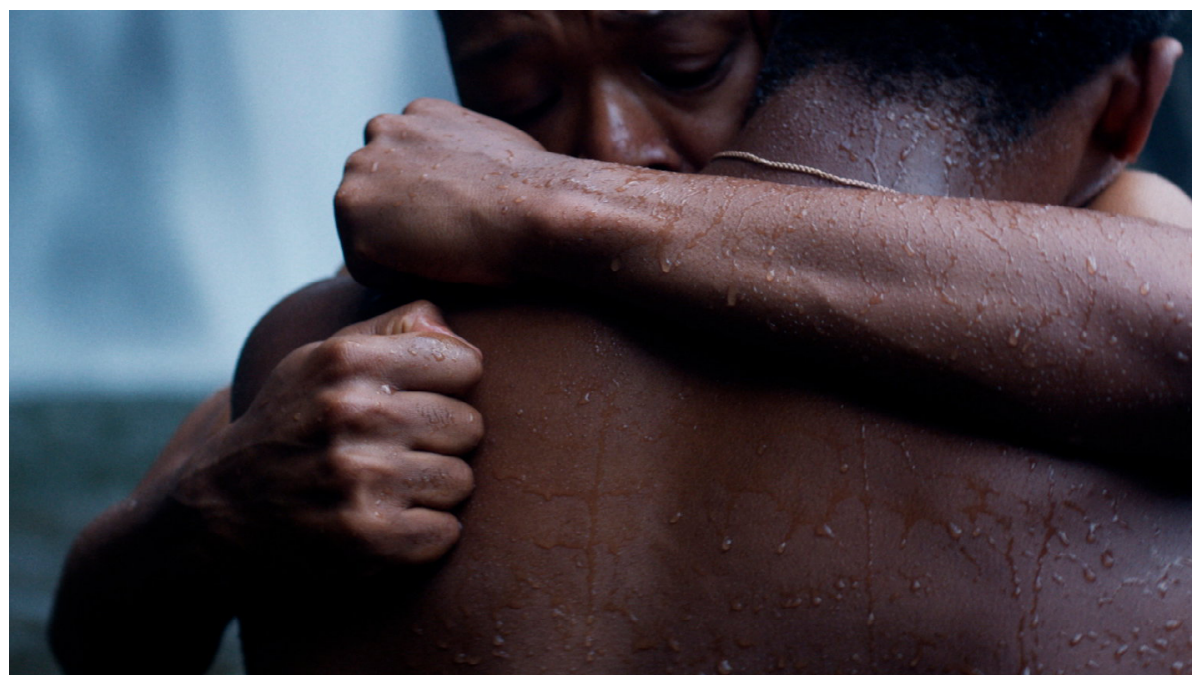

Rana (Inxeba. Zakazana ścieżka), 2017, reż. John Trengove, Francja-Holandia-Niemcy-RPA, dystr. Tongariro Releasing

starszyzny, przyjmując pozycję outsidera, opozycyjną wobec homogenicznej wspólnoty pozostałych inicjowanych. Choć chłopak ginie, zanim zdąży wkroczyć w dorosłość, to jego zachowanie podczas kolejnych etapów ulwaluko pozwala przypuszczać, że po powrocie do Johannesburga odrzuciłby zasady wpajane podczas inicjacji.

Ostracyzm, jakiego doświadczają podczas rytuału homoseksualni nastolatkowie, może przyczyniać się do tego, że jako dorośli ludzie będą oni cierpieć z powodu zinternalizowanej homofobii. Jak piszą Neil Henderson i Tamara Shefer, "homoseksualni mężczyźni przekroczyli pewne aspekty hegemonicznej męskości, lecz wciąż na wielu poziomach negocjują swoją 
tożsamość w odniesieniu do dominujących wyobrażeń na temat tego, co znaczy być mężczyzną w danym kontekście kulturowym" ${ }^{\prime 30}$. Przykładem bohatera zranionego przez próbę dostosowania się do wymagań sprzecznych $z$ jego własnymi pragnieniami jest Xolani. Dla kilku chwil czułości i intymności, mogących zaistnieć jedynie w wyjętym z codziennego porządku czasie rytuału, znosi on lata upokorzeń oraz przemocy, także ze strony ukochanego. Męskość Xhosa jest więc dla Xolaniego nie tylko prostą kwestią tożsamości, lecz również procesem bezustannej negocjacji.

Hegemoniczna męskość Xhosa, choć jest wpajana młodym mężczyznom w bardzo skodyfikowany, rytualny sposób, nie różni się od męskości afrykanerskiej tak bardzo, jak mogłoby się wydawać. Odrzucenie odmienności i zamknięcie wspólnoty jedynie we własnym kręgu szkodzi jednostkom, których tożsamość z różnych powodów nie pasuje do promowanej w danej społeczności normy. Rana jest zapisem konfliktów wewnątrz grupy etnicznej Xhosa oraz bezustannych negocjacji bohaterów między własną tożsamością a chęcią dopasowania się do wymagań i tradycji tej grupy. Manona i Hurst słusznie dostrzegają w ulwaluko metodę wytwarzania „opresyjnego modelu (heteronormatywnej) męskości”, który najmocniej uderza w najsłabsze, najmniej uprzywilejowane społecznie jednostki i wyklucza, zamiast jednoczyć ${ }^{31}$.

\section{PODSUMOWANIE}

Bohaterowie omawianych filmów są zmuszeni określać własną tożsamość w relacji do obowiązującego w ich społeczności dominującego wzorca męskości. W swoich dziełach Oliver Hermanus skupia się na białej męskości, której wzorce, wytworzone jeszcze w epoce kolonialnej, zostały jedynie umocnione $w$ dobie apartheidu, a jej pozostałości są dostrzegalne w strukturze społecznej RPA także dzisiaj. Moffie przybliża mechanizmy, które w latach 80. kształtowały tożsamość i wyobrażenia młodych południowoafrykańskich białych mężczyzn na temat męskości. Wpajane im wówczas przekonanie, że funkcjonuje ona jako hermetyczny, monolityczny byt

${ }^{30}$ N. Henderson, T. Shefer, Practices of Power and Abuse in Gay Male Relationships. An Exploratory Case Study of a Young, isiXhosa-speaking Man in the Western Cape, South Africa, "South African Journal of Psychology" 2008, t. 38, nr 1, s. 5.

${ }^{31}$ L. Manona, A. Hurst, "What Is It to Be a Man?”..., op. cit., s. 8. 
niechętny wszelkim odmiennościom, uprawniający do dominacji nad innymi grupami społecznymi, miało realny wpływ na życie tego pokolenia. O długofalowych konsekwencjach zinternalizowania tego wzorca hegemonicznej męskości opowiada natomiast Piękno, wskazując jednocześnie na możliwość stopniowego odchodzenia od niego w kolejnym pokoleniu. Na przecięciu dwóch pozostałych typów południowoafrykańskiej męskości wskazywanych przez Morrella sytuują się bohaterowie Rany Johna Trengove'a. Obecna podczas rytuału ulwaluko starszyzna Xhosa reprezentuje męskość afrykańską, silnie związaną z lokalnymi tradycjami i hierarchia$\mathrm{mi}$, natomiast Xolaniemu i nastoletniemu Kwandzie bliższa jest powiązana z urbanizacją czarna męskość. Silny indywidualizm młodszego bohatera sprawia jednak, że nie utożsamia się on w pełni z żadnym z tych wzorców i kwestionuje narzucane mu wyobrażenia o męskości Xhosa. Podobnie jak w przypadku filmów Hermanusa, również u Trengove'a opresyjny wzorzec męskości staje się dla bohaterów źródłem cierpienia i ma dla nich poważne, życiowe konsekwencje.

Sam mechanizm działania struktur hegemonicznej męskości afrykanerskiej i rdzennej jest bardzo zbliżony. Wpływ na tożsamość bohaterów mają osoby znajdujące się wyżej w hierarchii społecznej, jak wojskowi dowódcy czy lokalna starszyzna. Ponadto istotnym czynnikiem wymuszającym dostosowanie się do konkretnych wzorców postępowania jest presja ze strony rodziny i przyjaciół. Młodzi mężczyźni są uczeni, by przyjmować patriarchalny układ władzy za oczywistą kolej rzeczy oraz akceptować powszechność przemocy i wykluczanie jednostek kwestionujących ten rzekomo odwieczny porządek. $U$ starszych bohaterów zinternalizowane z biegiem lat konserwatywne wartości prowadzą do konfliktu wewnętrznego i zagubienia. Tożsamość ufundowana na sprzeczności między własnymi pragnieniami a wymogami męskości hegemonicznej przyczynia się do narastającego poczucia kryzysu.

Południowoafrykańskie kino queer w ostatnich latach nie stroni od rewizji historycznych i kwestionowania społecznych podziałów. Hermanus i Trengove udowadniają, że wzorce męskości hegemonicznej wypracowane w poprzednich stuleciach zawodzą, nie mogąc w pełni sprostać wyzwaniom współczesności. Dostrzegają jednak szansę na odnowę w bardziej otwartych postawach niektórych młodych mężczyzn, choć przemiana obowiązujących od dekad przekonań z pewnością nie będzie natychmiastowa ani łatwa. 
W artykule wykorzystano fragmenty pracy magisterskiej Autorki pt. Niebezpieczne zwiqzzki. Męska tożsamość w post-apartheidowym południowoafrykańskim kinie queer.

\section{BIBLIOGRAFIA}

Andrews G., The Boundaries of Desire and Intimacy in Post-apartheid South African Queer Film. Oliver Hermanus's Skoonheid, „Image and Text” 2018, nr 31, s. 30-47, http://www. scielo.org.za/pdf/it/n31/02.pdf (dostęp 29 X 2020).

Bly R., Żelazny Jan, przeł. J. Tittenbrun, Poznań 2017.

Botha M., Homosexuality and South African Cinema, „Kinema. A Journal for Film and Audiovisual Media" 2003, https://doi.org/10.15353/kinema.vi.1049.

Botha M., The Representation of Gays and Lesbians in South African Cinema 1985-2013, „Kinema. A Journal for Film and Audiovisual Media" 2013, https://doi.org/10.15353/kinema. vi.1285.

Bozzoli B., Marxism, Feminism and South African Studies, „Journal of Southern African Studies" 1983, t. 9, nr 2, s. 139-171, https://doi.org/10.1080/03057078308708055.

Carrigan T., Connell B., Lee J., Toward a New Sociology of Masculinity, "Theory and Society" 1985, nr 14, s. 551-604, https://doi.org/10.1007/BF00160017.

Connell R.W., Gender and Power. Society, the Person and Sexual Politics, Cambridge 1987.

Eliade M., Inicjacja, obrzędy, stowarzyszenia tajemne. Narodziny mistyczne, przeł. K. Kocjan, Kraków 1997.

Engel R., Gender and Race in the South African Film Industry. A Comparative Analysis of the Representation in South African Film Festival, "Communicatio" 2018, t. 44, nr 1, s. 16-33, https://doi.org/10.1080/02500167.2018.1444659.

Falkof N., ENG/AFR. White Masculinity in Two Contemporary South African Films, "Critical Arts" 2016, t. 30, nr 1, s. 15-30, https://doi.org/10.1080/02560046.2016.1164382.

Henderson N., Shefer T., Practices of Power and Abuse in Gay Male Relationships. An Exploratory Case Study of a Young, isiXhosa-speaking Man in the Western Cape, South Africa, "South African Journal of Psychology" 2008, t. 38, nr 1, https://doi.org/10.1177\%2F008 124630803800101.

Hino H., Leibbrandt M., Machema R. i in., Identity, Inequality and Social Contestation in the Post-Apartheid South Africa, [w:] From Divided Pasts to Cohesive Futures. Reflections on Africa, eds. H. Hino, A. Langer, J. Lonsdale, F. Stewart, Cambridge 2019, https://doi.org/10.1017/ 9781108645195.005.

hooks b., Black Looks. Race and Representation, New York, NY 1992.

Kareithi P.J., Hegemonic Masculinity in Media Contents, [w:] Media and Gender. A Scholarly Agenda for the Global Alliance on Media and Gender, red. A.V. Montiel, Paris 2014.

Magodyo T., Andipatin M., Jackson K., The Role of Xhosa Traditional Circumcision in Constructing Masculinity, "South African Journal of Psychology” 2017, t. 43, nr 3, https://doi.org/ 10.1177\%2F0081246316678176.

Maksymow K., Przeobrażenia polityczne i społeczne w Południowej Afryce - od apartheidu do czasów współczesnych, „Forum Politologiczne” 2012, t. 13, s. 517-532.

Manona L., Hurst A., "What Is It to Be a Man?". Rites, Hashtags, Outrage, „Image and Text" 2018, nr 32, http://dx.doi.org/10.17159/2617-3255/2018/n32a9. 
Mączko M., Niebezpieczne zwiqzzki. Męska tożsamość w post-apartheidowym południowoafrykańskim kinie queer, Kraków 2020.

Morrell R., Jewkes R., Lindegger G., Hegemonic Masculinity/Masculinities in South Africa. Culture, Power, and Gender Politics, „Men and Masculinities” 2012, t. 15, nr 1, s. 11-30, https://doi.org/10.1177\%2F1097184X12438001.

Morrell R., Of Boys and Men. Masculinity and Gender in Southern African Studies, „Journal of Southern African Studies" 1998, nr 24, s. 605-630, https://doi.org/10.1080/0305 7079808708593.

Sonnekus T., "We're not Faggots!". Masculinity, Homosexuality and the Representation of Afrikaner Men Who Have Sex with Men in the Film Skoonheid and Online, "South African Review of Sociology" 2013, t. 44, nr 1, s. 22-39, https://doi.org/10.1080/21528586.2013.78 4446.

Waal S. de, Etymological Note: on "Moffie”, [w:] Defiant Desire. Gay and Lesbian Lives in South Africa, eds. M. Gevisser, E. Cameron, New York, NY 1995.

\section{Netografia}

Bullock R., It's Hard to Be a Man, „Africa Geographic” 29 V 2015, https://africageographic.com/ stories/xhosa-circumcision-ritual-south-africa-its-hard-to-be-a-man/ (dostęp 29 X 2020).

Phillips R., Filmmaker Oliver Hermanus Discusses Beauty, „World Socialist Web Site” 4 VIII 2012, https://www.wsws.org/en/articles/2012/08/sfoh-a04.html (dostęp 29 X 2020).

Pillay R., South Africa Still Hasn't Won LGBTQ+ Equality. Here Are 5 Reasons Why, "World Economic Forum" 30 XI 2018, https://www.weforum.org/agenda/2018/11/south-africa-road-to-lgbtq-equality/ (dostęp $29 \times 2020$ ).

Sampson L., Cries and Whispers, „Sunday Times” 14 VIII 2011, https://www.timeslive.co.za/ sunday-times/lifestyle/2011-08-14-cries-and-whispers/ (dostęp 29 X 2020).

\section{I'M NOT LIKE YOU \\ HEGEMONIC MASCULINITY IN CONTEMPORARY SOUTH AFRICAN QUEER CINEMA}

Abstract: This article aims to describe common cultural types of masculinity in the South African society and illustrate their presence in contemporary local queer cinema. The historical and social circumstances that helped shape dominant South African forms of masculinity will be presented. The theory of hegemonic masculinity, first developed in the 1980s, will also be used. In the latter part of the article, three recent South African films will be analyzed: Beauty (Skoonheid, 2011, dir. O. Hermanus), The Wound (Inxeba, 2017, dir. J. Trengove), and Moffie (2019, dir. O. Hermanus). They will serve as examples of how Afrikaner and indigenous masculinities function, as well as what consequences await individuals who don't conform to said patterns.

Keywords: South African cinema, Queer Cinema, South Africa, hegemonic masculinity 